\title{
Utilization of increasing levels of cassava root meal in the diet of broiler
}

\section{Utilização de níveis crescentes de farelo de raiz de mandioca na dieta de frangos de corte}

Bianca Lima Ferreira1 ${ }^{\circledR}$, Daniela Aguiar Penha Brito ${ }^{1 *} \mathbb{C}^{\circ}$, Geraldo Fábio Viana

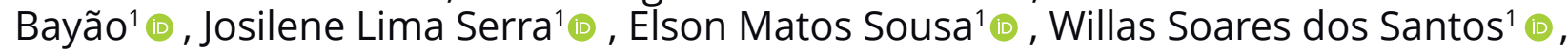
Tiago Castro Santos ${ }^{1}$ (1) , Vaneide Lima ${ }^{1}$ (])

'Instituto Federal de Educação, Ciência e Tecnologia do Maranhão, São Luiz, MA, Brasil

${ }^{*}$ Correspondent: danielabrito@ifma.edu.br

Received

June 12, 2021.

Accepted

August 4, 2021.

Published

October 6, 2021.

www.revistas.ufg.br/vet visit the website to get the how to cite in the article page.

\begin{abstract}
The objective of this study was to evaluate the effect of using increasing levels of cassava root meal in the diet of broilers, estimated by the performance and yield of carcasses, cuts, and viscera over, in the period 10 to 42 days of life. A completely randomized design was carried out, with four treatments and four repetitions. The experimental unit consisted of 16 male and female Cobb 500 chickens (a total of 256 birds) that were 10 to 42 days old. The treatments consisted of four diets with $0 \%$, $7.5 \%, 15 \%$, and $22.5 \%$ of cassava root meal (CRM) in three feeding programs. At 42 days old, four birds per unit were slaughtered and the carcass yield, main cuts, and edible viscera were evaluated. The inclusion of levels of $15 \%$ and $22.5 \%$ of CRM in the diet of broiler had a negative influence on weight gain, food consumption, and feed conversion in the initial period and in the overall growth of the birds. Carcass yield, cuts, and viscera were not influenced by the diet. Based on the results, it is recommended that a maximum of $7.5 \%$ of the cassava root bran may be used in the diet of broilers of the Cobb 500 strain, over 10 to 42 days, without compromising the zootechnical performance of the birds or the yield of edible carcasses, cuts, and viscera.
\end{abstract}

Keywords: Carcass yield, food, Manihot esculenta crantz, poultry farming, weight gain.

\section{Resumo}

Objetivou-se avaliar o efeito da utilização de níveis crescentes do farelo de raiz de mandioca (FRM) na ração de frangos de corte sob o desempenho e o rendimento de carcaças, cortes e vísceras, no período 10 a 42 dias de vida. Foi realizado um delineamento inteiramente ao acaso, com quatro tratamentos e quatro repetições. A unidade experimental foi representada por 16 frangos machos e fêmeas da linhagem Cobb 500. Os tratamentos consistiram em quatro rações com 0\%, 7,5\%, 15\% e $22,5 \%$ de farelo de raiz de mandioca em três programas de 
alimentação. Aos 42 dias, quatro aves por unidade foram abatidas e avaliados o rendimento de carcaça, principais cortes e vísceras comestíveis. A inclusão dos níveis de $15 \%$ e $22,5 \%$ de FRM na dieta dos frangos influenciou negativamente no ganho de peso, no consumo e na conversão alimentar no período inicial e de crescimento das aves. O rendimento de carcaça, cortes e vísceras não foram influenciados pela dieta. Com base nos resultados obtidos, recomenda-se o uso de até $7,5 \%$ do farelo de raiz de mandioca na dieta de frangos de corte da linhagem Cobb 500, no período de 10 a 42 dias, sem comprometer o desempenho zootécnico das aves e o rendimento de carcaças, dos cortes e vísceras comestíveis.

Palavras-chave: alimentação; avicultura; ganho de peso; Manihot esculenta crantz; rendimento de carcaça.

\section{Introduction}

The Brazilian poultry industry occupies a prominent position on the world stage, ranking third among the largest producers and first in exports ${ }^{(1)}$. The agricultural sector has been adopting strategies to make production more efficient and at a lower cost. One of those strategies is the use of a variety of ingredients in poultry feed to improve animal performance and reduce costs ${ }^{(2)}$.

The sources and energy content of chicken feed are considered the areas of the greatest challenge for poultry farming, which directly influence the economic success of production ${ }^{(3)}$. Corn is the most widely used energy ingredient in the formulation of poultry feed, but it is expensive and competes with use in human food especially in regions with low availability ${ }^{(4)}$. This reality stimulates the need to search for new food alternatives to replace the traditional energy sources used in poultry-diet formulations.

Cassava (Manihot esculenta crantz) and its products stand out as viable sources for inclusion in poultry feed in Brazil, as its crop production is high and widely spread throughout the country. Cassava is rich in highly digestible starch and has a low level of lipids ${ }^{(5)}$. The use of cassava root meal in animal feed is the most growing form of use in the world ${ }^{(6)}$. It is obtained from washed, grated, dried, and ground $\operatorname{root}^{(7)}$.

Studies on the use of cassava root meal in broiler chicken feed have been described in recent decades $(7 ; 8 ; 9 ; 10)$. There is considerable variation in the results $(5 \%$ to $50 \%)$, regarding the inclusion levels, to obtain zootechnical performance and carcass quality compatible with those obtained with a corn-based diet.

The level of inclusion of cassava meal in non-ruminant animal feed is limited by several intrinsic factors, such as a high fiber content, its cyanogenic glycoside content, and the presence of starchy polysaccharides ${ }^{(11 ; 12)}$. These factors can affect palatability, feed intake, weight gain, carcass weight, and even viability ${ }^{(13)}$. Other disadvantages of cassava include the low content of protein $(0.7 \%$ to $1.3 \%)$; carotenes; and micronutrients such as vitamin $A$, iron, and zinc, when compared to corn ${ }^{(13 ; 14)}$. The drying of roots in the sun, and the addition of protein sources and micronutrients have 
been used as efficient processing methods that can reduce the effects of cyanogenic glycosides and improve the nutritional value of cassava for birds ${ }^{(15)}$.

The inclusion of cassava meal in poultry farming has been described as promising, especially in regions with insufficient production or high competition for the use of corn in human and animal food ${ }^{(16)}$. Therefore, the objective of this work is to evaluate the performance and yield of the carcasses, cuts, and viscera of broiler chickens fed diets containing increasing amounts of cassava root meal from 10 to 42 days of the broiler's life.

\section{Material and methods}

The experiment was carried out from September to October 2019 in the poultry sector of the Federal Institute of Education, Science and Technology of Maranhão (IFMA), Maracanã campus, in the municipality of São Luís, Maranhão. The experimental design was completely randomized (DIC), with the birds distributed in four treatments and four replicates of 16 birds each, totaling 16 plots and 256 birds. The tested diets included cassava root meal at $0 \%$ (control treatment), $7.5 \%, 15 \%$, and $22.5 \%$.

The study involved 128 male and 128 female chickens of the commercial Cobb lineage, vaccinated against Marek, Gumboro, and Newcastle. The birds were housed in a masonry shed divided into boxes measuring $1.0 \times 2.0 \mathrm{~m}$, with a cement floor covered with wood shavings. Each division was equipped with an automatic pendular drinker and a tubular feeder, and the birds received water and feed ad libitum throughout the experimental period. A continuous lighting program (natural and artificial) was adopted, and the temperature and humidity of the experimental unit's environment were monitored.

The experimental diets were based on corn, soybean meal, and nucleus (synthetic amino acids, vitamins, minerals, and soybean oil), with or without whole cassava root bran. Cassava roots were acquired from a plantation located in the municipality of Marabá in the state of Pará. The preparation of cassava root meal (CRM) was performed using the Santos and Granjeiro method (17). The whole roots or pieces of cassava were washed and crushed, then the mass was spread on a canvas and left for 24 hours in the shade for the volatilization of the cyanogenic compounds. The material was then exposed to the sun for dehydration, then crushed again, and sieved to obtain bran of a smaller diameter.

The formulation of recommended levels for broilers was planned as described by Rostagno et al.(18) After bromatological analyses of the feed components for crude protein, crude fiber, crude energy, ether extract, mineral matter, calcium, and phosphorus, according to the Brazilian Compendium of Animal Feed ${ }^{(19)}$, three feeding programs were formulated. These were: 10 to 21 days of life (Table 1), 22 to 34 days of life (Table 2), and 35 to 42 days of life (Table 3). 
Table 1. Proximate chemical and energetic composition of the diets offered to broilers from 10 to 21 days of age

\begin{tabular}{|c|c|c|c|c|}
\hline \multirow{2}{*}{ Ingredients } & \multicolumn{4}{|c|}{ Cassava root bran inclusion levels (\%) } \\
\hline & $0 \%$ & $7,50 \%$ & $15 \%$ & $22,50 \%$ \\
\hline Crushed corn grain (\%) & 59,9 & 51,2 & 42,8 & 34,3 \\
\hline Soybean meal (\%) & 36,41 & 37,3 & 38,2 & 39,2 \\
\hline Cassava Root Bran (\%) & 0 & 7,5 & 15 & 22,5 \\
\hline${ }^{1}$ Nucleus (\%) & 4 & 4 & 4 & 4 \\
\hline Total & 100 & 100 & 100 & 100 \\
\hline \multicolumn{5}{|c|}{ Chemical composition calculated per $\mathrm{kg}$ of feed ${ }^{2}$} \\
\hline Metabolizable energy (Kcal/kg) & 3050 & 3050 & 3050 & 3050 \\
\hline Crude protein (\%) & 21,14 & 21,14 & 21,14 & 21,14 \\
\hline Calcium (\%) & 0,899 & 0,899 & 0,899 & 0,899 \\
\hline Available match (\%) & 0,449 & 0,449 & 0,449 & 0,449 \\
\hline Chlorine (\%) & 0,193 & 0,193 & 0,193 & 0,193 \\
\hline Potassium (\%) & 0,598 & 0,598 & 0,598 & 0,598 \\
\hline Sodium (\%) & 0,218 & 0,218 & 0,218 & 0,218 \\
\hline Digestible lysine (\%) & 1,189 & 1,189 & 1,189 & 1,189 \\
\hline Digestible Methionine+Cystine (\%) & 0,844 & 0,844 & 0,844 & 0,844 \\
\hline Digestible methionine (\%) & 0,464 & 0,464 & 0,464 & 0,464 \\
\hline Tryptophan (\%) & 0,19 & 0,19 & 0,19 & 0,19 \\
\hline
\end{tabular}

1Composition per kg of core: folic acid - $15 \mathrm{mg}$, pantothenic acid - $257 \mathrm{mg}$, copper - $142 \mathrm{mg}$, choline $7625 \mathrm{mg}$, cobalt - $2.5 \mathrm{mg}$, iron - $1250 \mathrm{mg}$, fluor - $412.5 \mathrm{mg}$, calcium - $211240 \mathrm{mg}$, phosphorus $41250 \mathrm{mg}$, sodium - $49110 \mathrm{mg}$, iodine - $25 \mathrm{mg}$, manganese - $1543 \mathrm{mg}$, lysine - $14309 \mathrm{mg}$, methionine - $29700 \mathrm{mg}$, niacin - $875 \mathrm{mg}$, selenium - $5.0 \mathrm{mg}$, zinc - $1068 \mathrm{mg}$, vitamin A - 250,000 iu/kg, vitamin B1 - $37 \mathrm{mg}$, vitamin B12 - $300 \mathrm{mcg}$, vitamin B2 - $125 \mathrm{mg}$, vitamin B6 - $25 \mathrm{mg}$, vitamin D3 -50,000 IU/kg, vitamin e - $375 \mathrm{lU} / \mathrm{kg}$ , vitamin $\mathrm{K}-62.5 \mathrm{mg}$, biotin $1 \mathrm{mg}$, phytase $-12500 \mathrm{u}$, virginiamycin - $375.0 \mathrm{mg}$, nicarbazine $-1100 \mathrm{mg}$, semduramycin $412.5 \mathrm{mg}$ and Bacillus subtilis $7,5 \times 10^{9} \mathrm{CFU}$.

${ }^{2}$ Based on Rostagno et al., 2011. 
Table 2. Proximate, chemical and energetic composition of the diets offered to broilers from 22 to 34 days of age

\begin{tabular}{|c|c|c|c|c|}
\hline \multirow{2}{*}{ Ingredients- } & \multicolumn{4}{|c|}{ Cassava root bran inclusion levels (\%) } \\
\hline & $0 \%$ & $7,50 \%$ & $15 \%$ & $22,50 \%$ \\
\hline Crushed corn grain (\%) & 59,9 & 51,2 & 42,8 & 34,3 \\
\hline Soybean meal (\%) & 36,41 & 37,3 & 38,2 & 39,2 \\
\hline Cassava Root Bran (\%) & 0 & 7,5 & 15 & 22,5 \\
\hline${ }^{1}$ Nucleus (\%) & 4 & 4 & 4 & 4 \\
\hline Total & 100 & 100 & 100 & 100 \\
\hline \multicolumn{5}{|c|}{ Chemical composition calculated per kg of feed ${ }^{2}$} \\
\hline Metabolizable energy (Kcal/kg) & 3050 & 3050 & 3050 & 3050 \\
\hline Crude protein (\%) & 21,14 & 21,14 & 21,14 & 21,14 \\
\hline Calcium (\%) & 0,899 & 0,899 & 0,899 & 0,899 \\
\hline Available match (\%) & 0,449 & 0,449 & 0,449 & 0,449 \\
\hline Chlorine (\%) & 0,193 & 0,193 & 0,193 & 0,193 \\
\hline Potassium (\%) & 0,598 & 0,598 & 0,598 & 0,598 \\
\hline Sodium (\%) & 0,218 & 0,218 & 0,218 & 0,218 \\
\hline Digestible lysine (\%) & 1,189 & 1,189 & 1,189 & 1,189 \\
\hline Digestible Methionine+Cystine (\%) & 0,844 & 0,844 & 0,844 & 0,844 \\
\hline Digestible methionine (\%) & 0,464 & 0,464 & 0,464 & 0,464 \\
\hline Tryptophan (\%) & 0,19 & 0,19 & 0,19 & 0,19 \\
\hline
\end{tabular}

${ }^{1}$ Composition per kg of core: folic acid - $20 \mathrm{mg}$, pantothenic acid - $300 \mathrm{mg}$, copper - $250 \mathrm{mg}$, choline $2000 \mathrm{mg}$, iron - $1250 \mathrm{mg}$, fluor - $325 \mathrm{mg}$, calcium - $214000 \mathrm{mg}$, phosphorus - $32500 \mathrm{mg}$, sodium 36700 $\mathrm{mg}$, iodine $-30 \mathrm{mg}$, manganese $-2000 \mathrm{mg}$, lysine $-12214 \mathrm{mg}$, methionine $-26500 \mathrm{mg}$, niacin $-800 \mathrm{mg}$, selenium - $7.0 \mathrm{mg}$, zinc - $1500 \mathrm{mg}$, vitamin a - 175,000ui/kg, vitamin b1 -40mg, vitamin B1 - $40 \mathrm{mg}$, vitamin B12 - 250mcg, vitamin B2 - 112mg, vitamin B6 - $55 \mathrm{mg}$, vitamin D3 - 50,000 IU/ $\mathrm{kg}$, vitamin E $275 \mathrm{lU} / \mathrm{kg}$, vitamin K - $40 \mathrm{mg}$, 6-phytase $-12500 \mathrm{mg}$, halquinol- 750.0 and salinomycin - $1500 \mathrm{mg}$.

${ }^{2}$ Based on Rostagno et al., 2011. 
Table 3. Proximate, chemical and energetic composition of the diets offered to broilers from 35 to 42 days of age

\begin{tabular}{|c|c|c|c|c|}
\hline \multirow{2}{*}{ Ingredients } & \multicolumn{4}{|c|}{ Cassava root bran inclusion levels (\%) } \\
\hline & $0 \%$ & $7,50 \%$ & $15 \%$ & $22,50 \%$ \\
\hline Crushed corn grain (\%) & 67,63 & 59,03 & 50,42 & 41,83 \\
\hline Soybean meal (\%) & 28,37 & 29,47 & 30,58 & 31,67 \\
\hline Cassava Root Bran (\%) & 0 & 7,5 & 15 & 22,5 \\
\hline${ }^{1}$ Nucleus (\%) & 4 & 4 & 4 & 4 \\
\hline Total & 100 & 100 & 100 & 100 \\
\hline \multicolumn{5}{|c|}{ Chemical composition calculated per kg of feed ${ }^{2}$} \\
\hline Metabolizable energy (Kcal/kg) & 3200 & 3200 & 3200 & 3200 \\
\hline Crude protein (\%) & 18,31 & 18,31 & 18,31 & 18,31 \\
\hline Calcium (\%) & 0,775 & 0,775 & 0,775 & 0,775 \\
\hline Available match (\%) & 0,386 & 0,386 & 0,386 & 0,386 \\
\hline Chlorine (\%) & 0,172 & 0,172 & 0,172 & 0,172 \\
\hline Potassium (\%) & 0,593 & 0,593 & 0,593 & 0,593 \\
\hline Sodium (\%) & 0,198 & 0,198 & 0,198 & 0,198 \\
\hline Digestible lysine (\%) & 1,048 & 1,048 & 1,048 & 1,048 \\
\hline Digestible Methionine+Cystine (\%) & 0,755 & 0,755 & 0,755 & 0,755 \\
\hline Digestible methionine (\%) & 0,419 & 0,419 & 0,419 & 0,419 \\
\hline Tryptophan (\%) & 0,178 & 0,178 & 0,178 & 0,178 \\
\hline
\end{tabular}

${ }^{1}$ Composition per kg of core: folic acid - $4 \mathrm{mg}$, pantothenic acid - $139 \mathrm{mg}$, cobalt - $1 \mathrm{mg}$, copper - $142 \mathrm{mg}$, choline - 3275mg, iron - $1250 \mathrm{mg}$, fluor - $600 \mathrm{mg}$, calcium - $216780 \mathrm{mg}$, phosphorus - $60000 \mathrm{mg}$, sodium $49110 \mathrm{mg}$, iodine $-21 \mathrm{mg}$, manganese $-1234 \mathrm{mg}$, methionine $-17320 \mathrm{mg}$, niacin $-425 \mathrm{mg}$, selenium -5.5 $\mathrm{mg}$, vitamin A - 125,000 Ul/kg, vitamin B1 -8mg, vitamin B12 - 150mcg, vitamin B2 - $60 \mathrm{mg}$, vitamin B6 $14 \mathrm{mg}$, vitamin D3 - 25,000 IU/kg, vitamin E - $175 \mathrm{IU} / \mathrm{kg}$, vitamin $\mathrm{K}-29 \mathrm{mg}$, zinc $-854 \mathrm{mg}$, biotin - $0.5 \mathrm{mg}$ and Bacillus subtilis $7.5 \times 10^{9} \mathrm{CFU}$.

${ }^{2}$ Based on Rostagno et al., 2011.

The birds were weighed on the $10^{\text {th }}, 22^{\text {nd }}, 28^{\text {th }}, 34^{\text {th }}$, and $42^{\text {nd }}$ day of life. Weighing of leftover feed from each experimental plot was performed daily. Records of dead birds were noted. The parameters evaluated were weight gain (WG), feed intake (FI), and feed conversion (FC). Weight gain was determined by the difference in final weight and the initial weight of each stage of life. The average feed intake was calculated by the 
difference between the amount of feed provided, and the waste and leftovers of the experimental feed.

Feed conversion was calculated from the ratio of feed intake and weight gain for each treatment during the feeding program period, in $\mathrm{kg} / \mathrm{kg}$. Viability was determined individually per plot by the number of birds housed on day 10 and the number of birds alive at day 42 , expressed as a percentage, with mortality being recorded daily and following the formula:

$$
\mathrm{VB}=[1-(\mathrm{MORT} / \mathrm{AA}) \times 100]
$$

where $\mathrm{VB}=$ viability; $\mathrm{MORT}=$ mortality that occurred in the period; $\mathrm{AA}=$ number of birds in the housing. The Productive Efficiency (PE) was evaluated according to the formula: $[(W G \times V B) /($ days until the end of the experiment $\times F C)] \times 100$.

The carcasses were plucked, eviscerated without feet, head, and neck, weighed, and the carcass yield was calculated by the ratio of newly prepared carcass weight and body weight at slaughter. The carcasses were sectioned into the breast, wing, thigh and drumstick, back, paws, neck, and head cuts. The cuts, viscera (heart, gizzard, liver, intestine), and abdominal fat were weighed. The yield of the cuts was determined relative to the newly prepared carcass weight. All income data were expressed in grams for weight and percentages ${ }^{(20 ; 21)}$.

Data were subjected to analysis of variance and means were compared by Tukey's test using the InStat statistical program (Graphpad Instat: GraphPad Software Oberlin, San Diego-CA, USA). Regression analysis was performed as a function of cassava root meal inclusion levels using the statistical program Past 4.07b.

The work was approved by the Ethics Committee on Animal Use in Education and Research (CEUA) of the IFMA, $n^{\circ}$ 23249.038473.2018-18.

\section{Results and discussion}

The average temperature values obtained during the day (from 8 am to $4 \mathrm{pm}$ ) and night were $30.99{ }^{\circ} \mathrm{C}$ and $26.77{ }^{\circ} \mathrm{C}$, respectively, and the relative humidity was $61.40 \%$ and $74.73 \%$, respectively. Therefore, the study was carried out in a high-temperature environment, with the birds subjected to heat stress according to the classification by the Cobb broiler manual(22). Similar results were found by Ferreira et al. ${ }^{(7)}$ when evaluating the performance of broiler pullets fed with diets containing different amounts of cassava root meal.

The broilers that had the diet of 7.5\% of CRM had higher weight gain (WG $=652.18 \mathrm{~g}$ ), lower feed conversion ( $F C=1.37)$, and better production efficiency ( $P E=417.3)$, with significant differences when compared to treatments with higher levels of CRM inclusion (Table 4). Regression analysis showed a decreasing linear behavior for weight gain and production efficiency, while feed intake showed an increasing linear effect up to 21 days of growth, as represented by the equations in Table 5. It was observed that birds fed diets containing CRM with levels above $7.5 \%$ showed lower performance in 
these parameters. Feed intake and viability were not influenced by the inclusion of CRM in broilers feed for up to 21 days (Table 4).

Table 4. Performance of broilers from mixed batches fed with rations containing increasing levels of cassava root meal (CRM) from 10 to 42 days

\begin{tabular}{|c|c|c|c|c|c|c|c|}
\hline \multirow{2}{*}{ Days } & \multirow{2}{*}{ Parameters } & \multicolumn{4}{|c|}{ WCM inclusion levels } & \multirow{2}{*}{$C V *(\%)$} & \multirow{2}{*}{$\mathbf{P}$} \\
\hline & & $0 \%$ & $7,50 \%$ & $15 \%$ & $22,50 \%$ & & \\
\hline \multirow{7}{*}{$10-21$} & Initial BW (g) & 167,68 & 167,67 & 165,67 & 167,43 & 0,83 & 0,919 \\
\hline & WG (g) & $642,8^{\mathrm{ac}}$ & $652,2^{a}$ & $610,2^{b}$ & $614,9^{\mathrm{bc}}$ & 3,5 & $0,004 *$ \\
\hline & $\mathrm{Fl}(\mathrm{g})$ & 860 & 897,2 & 875,5 & 890,5 & 2,42 & 0,519 \\
\hline & FC & $1,36^{a}$ & $1,37^{\mathrm{a}}$ & $1,43^{b}$ & $1,44^{b}$ & 3,05 & $0,005^{*}$ \\
\hline & VB (\%) & 100 & 96,88 & 100 & 98,44 & 3,43 & 0,6 \\
\hline & $\mathrm{PE}$ & $426,9^{a}$ & $417,3^{\mathrm{ab}}$ & $386,7^{b}$ & $380,1^{b c}$ & 6,29 & $0,024^{*}$ \\
\hline & Final BW (g) & $810,46^{a c}$ & $819,88^{a}$ & $775,87^{b}$ & $782,88^{b c}$ & 2,85 & 0,012 \\
\hline \multirow{6}{*}{$22-34$} & WG (g) & 1.135 & 1.135 & 1.077 & 1.078 & 3,56 & 0,063 \\
\hline & $\mathrm{Fl}(\mathrm{g})$ & $1.921^{\mathrm{a}}$ & $1.975^{b}$ & $1.976^{\mathrm{b}}$ & $1.963^{\mathrm{ab}}$ & 1,57 & $0,022 *$ \\
\hline & FC & $1,69^{a}$ & $1,74^{\mathrm{ab}}$ & $1,83^{b}$ & $1,82^{\mathrm{b}}$ & 4,32 & $0,009 *$ \\
\hline & VB (\%) & 98,43 & 100 & 100 & 100 & 3,14 & 0,791 \\
\hline & PE & 502,3 & 502,1 & 452 & 455 & 7,38 & 0,112 \\
\hline & Final BW (g) & $1.945^{\mathrm{a}}$ & $1.954^{\mathrm{a}}$ & $1.853^{\mathrm{b}}$ & $1.860^{\mathrm{b}}$ & 2,89 & 0,001 \\
\hline \multirow{6}{*}{$35-42$} & WG (g) & 535,5 & 559,4 & 531,3 & 585,1 & 8,55 & 0,398 \\
\hline & $\mathrm{Fl}(\mathrm{g})$ & 1.410 & 1.477 & 1.441 & 1.482 & 3,29 & 0,114 \\
\hline & FC & 2,64 & 2,67 & 2,7 & 2,53 & 6,89 & 0,6 \\
\hline & VB (\%) & 100 & 100 & $100^{a}$ & 98,33 & 1,56 & 0,791 \\
\hline & PE & 254,8 & 267 & 246,8 & 285,8 & 14,05 & 0,661 \\
\hline & Final BW (g) & $2.480^{\mathrm{ab}}$ & $2.517^{a}$ & $2.384^{b}$ & $2.445^{\mathrm{ab}}$ & 2,9 & 0,031 \\
\hline
\end{tabular}

Means with equal letters, in the lines, do not differ in Tukey's Test ( $p>0,05) ; C V=$ coefficient of variation, $\mathrm{BW}=$ avarage body weight, $\mathrm{WG}=$ avarage weight gain, $\mathrm{FI}=$ avarage feed intake, $\mathrm{FC}=$ feed conversion, $\mathrm{VB}$ $=$ viability and $P E=$ production efficiency. 
Table 5. Regression equations for performance parameters of broilers from 10 to 34 days of age

\begin{tabular}{ccccc}
\hline Days & Parameters & Regression Equation & p value & $\mathbf{R}^{2}$ \\
\hline out.-21 & WG & $\mathrm{Y}=658,74-2,5528 \mathrm{X}$ & 0,0002 & 0,43 \\
& $\mathrm{FI}$ & $\mathrm{Y}=1919.2+3.5534 \mathrm{X}$ & 0 & 0,22 \\
& $\mathrm{FC}$ & $\mathrm{Y}=1,315+0,0049 \mathrm{X}$ & $2,49 \times 10^{-5}$ & 0,63 \\
\hline $22-34$ & PE & $\mathrm{Y}=435,67-2,9262 \mathrm{X}$ & $3,50 \times 10^{-5}$ & 0,6 \\
\hline
\end{tabular}

$\mathrm{BW}=$ avarage weight, $\mathrm{WG}=$ avarage weight gain, $\mathrm{Fl}=$ avarage feed intake, $\mathrm{FC}=$ feed conversion, $\mathrm{VB}=$ viability and $\mathrm{PE}=$ production efficiency.

These results are in agreement with those reported by Ferreira et al. ${ }^{(7)}$ who used $8.81 \%$ inclusion and Ferreira et al. ${ }^{(8)}$ who used levels of up to $5.1 \%$ in the broiler feed in the initial phase, showing better results for feed conversion in this period.

The influence of diets containing cassava on the weight gain of broilers studied in other studies corroborates with the observation that an increased amount of cassava in the diet of broilers may reduce weight gain and worsen feed conversion ${ }^{(12)}$. This is possibly because of the lower efficiency in the use of starch contained in cassava root flour by birds in the initial stage of life ${ }^{(23)}$. Young broiler chickens still do not have villi that are of an adequate height and size, and they have low enzymatic efficiency making it harder for them to make good use of foods with low digestibility ${ }^{(12 ; 10)}$.

In the period from 22 to 34 days, there was an increase in the average feed intake of CRM, with significant differences in the intake of the diet containing $7.5 \%$ and $15 \%$ of CRM compared to that without CRM (0\%). These results may suggest that the increase in the level of fibrous foods, such as CRM, significantly increased consumption, a factor that directly influenced the feed conversion by birds (Table 4). The regression analysis shows an increasing linear relationship between feed intake and feed conversion (see equations in Table 5).

It is known that in the growth phase, the bird consumes the most food as it is the period during which its digestive system enters the final period of maturation, consequently leading to the final growth and development of the bird(24). Thus, it is assumed that the increase in feed intake of diets with CRM reflects the maturation of the low dietdigesting ability from the initial phase of the broiler's life.

The results of the feed intake by the birds determined the differences in feed conversion. These results are important, as feed conversion is economically significant, being considered the most important parameter for broiler rearing. 
It was observed that the performance parameters were not influenced by different diets in the period of 35 to 42 days (Table 4), suggesting that there may be a compensatory gain in birds during this time of life as there were no differences between the means. Distinct results for the final phase differ from the results of Nascimento et al. ${ }^{(10)}$ who observed a decreasing effect on weight gain as the amount of scrapings of cassava root was increased in the finishing phase of the chickens' feed. However, the worst performance for feed conversion and weight gain was at the level of $15 \%$ of cassava root scrapings instead of corn, which is similar to what was found in this study (Table 4).

There were significant differences in body weight at slaughter (BWS) for males and females, and the carcass weight (CW) of females associated with the 15\% cassava feed (Table 6). In males, the weight reduction was around $300 \mathrm{~g}$ compared to the diet without CRM. However, females gained weight ( 162 grams) when fed a diet containing $7.5 \%$ of CRM.

Table 6. The yield of carcasses, cuts, and offals of chickens on diets containing different levels of cassava root meal

\begin{tabular}{|c|c|c|c|c|c|c|c|c|}
\hline \multirow{3}{*}{ Parameters } & \multicolumn{8}{|c|}{ Cassava Root Meal Levels } \\
\hline & \multicolumn{2}{|c|}{$0 \%$} & \multicolumn{2}{|c|}{$7,50 \%$} & \multicolumn{2}{|c|}{$15 \%$} & \multicolumn{2}{|c|}{$22,50 \%$} \\
\hline & Males & Females & Males & Females & Males & Females & Males & Females \\
\hline BWS (g) & $2675^{\mathrm{aA}}$ & $2138^{\mathrm{bB}}$ & $2538^{\mathrm{aA}}$ & $2300^{\mathrm{bA}}$ & $2363^{\mathrm{aB}}$ & $2113^{\mathrm{bB}}$ & $2400^{\mathrm{aB}}$ & $2150^{\mathrm{bB}}$ \\
\hline CW (g) & 1939 a & $1570^{\mathrm{bA}}$ & $1860^{\mathrm{aA}}$ & $1686^{\mathrm{bA}}$ & 1699 ав & $1535^{\mathrm{bB}}$ & $1741^{\mathrm{aA}}$ & $1557^{\mathrm{bB}}$ \\
\hline CY (\%) & $72,4^{\mathrm{aA}}$ & $73,5^{\mathrm{aA}}$ & $73,3^{\mathrm{aA}}$ & $73,3^{\mathrm{aA}}$ & $71,8^{\mathrm{aA}}$ & $72,7^{\mathrm{aA}}$ & $72,5^{\mathrm{aA}}$ & $72,4^{\mathrm{aA}}$ \\
\hline Breast (\%) & $29,3^{\mathrm{aA}}$ & $33,6^{\mathrm{bA}}$ & $29,9^{\mathrm{aA}}$ & $31,1^{\mathrm{aA}}$ & $29,7^{\mathrm{aA}}$ & $32,0^{\mathrm{bA}}$ & $30,1^{\mathrm{aA}}$ & $31,9^{\mathrm{aA}}$ \\
\hline $\mathrm{T}+\mathrm{D}(\%)$ & $26,9^{\mathrm{aA}}$ & $27,1^{\mathrm{aA}}$ & $29,3^{\mathrm{aA}}$ & $28,1^{\mathrm{aA}}$ & $30,1^{\mathrm{aA}}$ & $28,3^{\mathrm{bA}}$ & $30,3^{\mathrm{aA}}$ & $28,0^{\mathrm{bA}}$ \\
\hline Back (\%) & $19,0^{\mathrm{aA}}$ & $20,2^{\mathrm{aA}}$ & $18,9^{\mathrm{aA}}$ & $18,7^{\mathrm{aA}}$ & $17,2^{\mathrm{aA}}$ & $17,4^{\mathrm{aA}}$ & $17,8^{\mathrm{aA}}$ & $17,6^{\mathrm{aA}}$ \\
\hline Wing (\%) & $5,2^{\mathrm{aA}}$ & $5,5^{\mathrm{aA}}$ & $5,1^{\mathrm{aA}}$ & $4,9^{\mathrm{aA}}$ & $4,8^{\mathrm{aA}}$ & $5,1^{\mathrm{aA}}$ & $5,2^{\mathrm{aA}}$ & $5,1^{\mathrm{aA}}$ \\
\hline PNH (\%) & $9,7^{\mathrm{aA}}$ & $9,0^{\mathrm{aA}}$ & $10,1^{\mathrm{aA}}$ & $9,5^{\mathrm{aA}}$ & $10,4^{\mathrm{aA}}$ & $9,6^{\mathrm{aA}}$ & $10,1^{\mathrm{aA}}$ & $9,6^{\mathrm{aA}}$ \\
\hline Viscera (\%) & $10,4^{\mathrm{aA}}$ & $11,2^{\mathrm{aA}}$ & $10,8^{\mathrm{aA}}$ & $11,0^{\mathrm{aA}}$ & $11,5^{\mathrm{aA}}$ & $11,6^{\mathrm{aA}}$ & $11,7^{\mathrm{aA}}$ & $11,7^{\mathrm{aA}}$ \\
\hline AF (\%) & $0,7^{\mathrm{aA}}$ & $0,8^{\mathrm{aA}}$ & $0,7^{\mathrm{aA}}$ & $0,8^{\mathrm{aA}}$ & $0,7^{\mathrm{aA}}$ & $0,9^{\mathrm{aA}}$ & $0,8^{\mathrm{aA}}$ & $1,0^{\mathrm{aA}}$ \\
\hline Liver (\%) & $1,8^{\mathrm{aA}}$ & $1,9^{\mathrm{aA}}$ & $2,0^{\mathrm{aA}}$ & $2,3^{\mathrm{bA}}$ & $2,0^{\mathrm{aA}}$ & $2,2^{\mathrm{aA}}$ & $1,7^{\mathrm{aA}}$ & $1,9^{\mathrm{aA}}$ \\
\hline Heart (\%) & $0,4^{\mathrm{aA}}$ & $0,4^{\mathrm{aA}}$ & $0,5^{\mathrm{aA}}$ & $0,4^{\mathrm{aA}}$ & $0,4^{\mathrm{aA}}$ & $0,4^{\mathrm{aA}}$ & $0,5^{\mathrm{aA}}$ & $0,4^{\mathrm{aA}}$ \\
\hline Gizzard (\%) & $1,5^{\mathrm{aA}}$ & $1,6^{\mathrm{aA}}$ & $1,6^{\mathrm{aA}}$ & $1,6^{\mathrm{aA}}$ & $1,7^{\mathrm{aA}}$ & $1,6^{\mathrm{aA}}$ & $1,6^{\mathrm{aA}}$ & $1,6^{\mathrm{aA}}$ \\
\hline I (\%) & $9,2^{\mathrm{aA}}$ & $9,3^{\mathrm{aA}}$ & $9,5^{\mathrm{aA}}$ & $8,6^{\mathrm{bB}}$ & $10,4^{\mathrm{aA}}$ & $9,8^{\mathrm{aA}}$ & $10,5^{\mathrm{aA}}$ & $10,1^{\mathrm{aA}}$ \\
\hline
\end{tabular}

Means with equal letters in the lines do not differ in Tukey Test ( $p>0.05)$. Lowercase letters: different letters show significant differences between males and females within the same treatment; capital letters: different letters show significant differences between males and females between treatments. BWS = cody weight at slaughter; $C W=$ carcass weight; $C Y=$ carcass yield; $T+D=$ thigh and drumstick; $P N H=$ paws neck head; $V$ = viscera; $A F=$ abdominal fat; $I=$ intestine 
The carcass yield, main cuts, and edible viscera were not influenced $(p>0.05)$ by diets with different levels of CRM (Table 5). Similarly, Ferreira et al.(7) observed that the whole cassava scraping used in broiler chickens from 1 to 42 days of age did not affect carcass characteristics, the weight of the main cuts, or the viscera when the diet was properly balanced.

\section{Conclusion}

Cassava root meal can be used in the diet of broiler chickens of the Cobb 500 lineage, for a period of 10 to 42 days of life, up to $7.5 \%$ of the content without affecting the broiler performance, carcass yield, cuts, and edible viscera yield.

\section{Conflict of interests}

The authors declare no conflict of interest.

\section{Acknowledgments}

The authors would like to acknowledge the assistance of Fundação de Amparo à Pesquisa ao Desenvolvimento Científico e Tecnológico do Maranhão (FAPEMA) for financial support in conducting this research.

\section{References}

1. ABPA. Associação brasileira de proteína animal. Relatório anual de 2020. Disponível em: (https://abpabr.org/wp-content/uploads/2020/05/abpa_relatorio_anual_2020_portugues_web.pdf).

2. Vieira DVG, Alves CF, Alves FL, Parente IP, Conti ACM, Souza MS, Melo TS, Calvalcanti DT, Fonteles NLO, Vilanova CS, Silva EM. Principais aspectos da inter-relação nutrição e imunidade em aves sob estresse. Nutritime. 2015; 12 (6). Portuguese. Disponível em: (https://www.nutritime.com.br/site/artigo-342principais-aspectos-da-interrelacao-nutricao-e-imunidade-em-aves-sob-estresse/).

3. Alencar DP, Maciel MP, Botelho LFR, Caldeira LA, Souza LFM, Silva DB, Moura VHS. Feijão guandu cru na alimentação de frangos caipiras em sistema de criação semi-intensivo. Pesq. agrop. bras. 2014; 49 (9): 737-744. Portuguese. DOI: (https://doi.org/10.1590/S0100-204X2014000900010).

4. De Paula S, Welisany et al. Inclusão do farelo de bolacha na alimentação de frangos de corte de linhagem caipira. Brazilian Journal of Development. 2020; 6 (6): 39810-39824. English. DOI: (doi.org/ 10.34117/bjdv6n6-500).

5. Valli TL, Lorenzi JO. Cultivares melhoradas de mandioca como instrumento de inovação, segurança alimentar, competitividade e sustentabilidade: contribuições do Instituto Agronômico de Campinas (IAC). Cadernos de Ciência e Tecnologia. 2014; 31(1): 15-34. Portuguese. DOI: (http://dx.doi.org/10.35977/01041096.cct2014.v31.19441). 
Utilization of increasing levels of cassava root meal in the diet of broiler

Ferreira B L et al.

6. FAO. Food and Agriculture Organization of the United Nations. Food Outlook. Biannual report on global food markets. 2014. English. Disponível em: (http://www.fao.org/3/i4136e/i4136e.pdf).

7. Ferreira AHC, Lopes JB, Abreu ALT, Figueiredo AV, Ribeiro MN, Silva FES, Merval RR. Raspa integral da raiz de mandioca para frangas de um a 42 dias de idade. Rev. Bras. Saúde Prod. Anim. 2012; 13 (1): 160-172. Portuguese. Disponível em: (https://www.scielo.br/j/rbspa/a/X6rBQPQKJkR9xMCgCVLBJmc/ ?lang=pt\&format=pdf).

8. Ferreira AHC, Lopes JB, Abreu MLT, Júnior HAS, Araújo FS, Saraiva. Whole scrapings of cassava root in diets for broilers from 1 to 21 days of age. Acta Scientiarum. Animal Sciences. 2014; 36(4): 357-362. English. DOI: (https://doi.org/10.4025/actascianimsci.v36i4.23368).

9. Kana JR, Defang FH, Mafouo GH, Ngouana R, Moube NM, Ninjo J, et al. Effect ofvcassva meal supplemented with a combination of palm oil and cocoa husk as alternative energy source on broiler growth. Arch Zootech. 2012; 15 (4): 17-25. English. Disponível em: (https://www.researchgate.net/ publication/259223889).

10. Nascimento G, Costa F, Júnior V, Barros L. Efeitos da substituição do milho pela raspa de mandioca na alimentação de frangos de corte, durante as fases de engorda e final. Ciênc. agrotec. 2005; 29 (1): 200-207. Portuguese. DOI: (https://doi.org/10.1590/S1413-70542005000100025).

11. Nambisan B. Strategies for elimination of cyanogens from cassava for reducing toxicity and improving food safety. Food and chemical toxicology, Exeter. 2011; 49 (3): 690-693. English. (https://doi.org/10.1016/ j.fct.2010.10.035).

12. Sousa JPL, Rodrigues KF, Albino LFT, Santos Neta ER, Vaz RGMV, Parente IP, Silva GF, Amorim AF. Bagaço de mandioca em dietas de frango de corte. Revista brasileira de saúde e produção animal. 2012; 13 (4): 1044-1053. Portuguese. Disponível em:(https://www.scielo.br/j/rbspa/a/ PhV3tBLkGFzm4mLhrTybQkC/?lang=pt\&format=pdf).

13. Morgan NK, Choct M. Cassava. Nutrient composition and nutritive value in poultry diets. Animal Nutrition. 2016; 2: 253-261. English. (http://doi.org/10.1016/j.aninu.2016.08.010).

14. Ngiki YU, Igwebuike JU, Moruppa SM. Utilization of cassava products for poultry feeding: a review. Int J Sci Tech. 2014; 2 (6): 48-59. English. Disponível em: (http://www.internationaljournalcorner.com/ index.php/theijst/article/view/128153/88818).

15. Duarte ME, FSA Cunha, GRQ Lana. Silagem de mandioca na alimentação de codornas. Rev. Cient. Prod. Anim. 2010; 12 (2): 173-176. Portuguese. DOI: (http://dx.doi.org/10.15528/2176-4158/ rcpa.v12n2p173-176)

16. Aniebo AO. Effect of cassayeast produced from varying combinations of cassava (Manihot esculenta) and brewers' dried yeast (Saccharomyces cerevicea) on broiler performance. Revista Científica UDO Agrícola. 2011; 11 (1): 161-166. English. (cg11017.pdf)

17. Santos JFDOS, Granjeiro JIT. Desempenho de aves caipira de corte alimentadas com mandioca e 
palma forrageira enriquecidas com levedura. Tecnologia e Ciência Agropecuária, João Pessoa, 2012; 6 (2): 49-54. Portuguese. Disponível em: (tca6209.pdf).

18. Rostagno HS, Albino LFT, Donzele JL, Gomes PC, Oliveira RF, Lopes DC, Ferreira AS, Barreto SLT. Tabelas brasileiras para aves e suínos: composição de alimentos e exigências nutricionais. Viçosa: UFV, 2011. p. 252. Portuguese. Disponível em: (https://edisciplinas.usp.br/pluginfile.php/4532766/ mod resource/content/1/Rostagno\%20et\%20al\%202017.pdf).

19. Compêndio Brasileiro de Alimentação Animal 2017. Proteína Bruta. Guia de Métodos Analíticos. Método 46: 207-216. Revisão 2017.

20. Almeida APS, Pinto MF, Poloni LB, Ponsano EHG, Garcia NETOM. Efeito do consumo de óleo de linhaça e de vitamina $\mathrm{E}$ no desempenho e nas características de carcaça de frango de corte. Arquivo Brasileiro de medicina Veterinária e Zootecnia, Belo Horizonte, 2009; 61 (3): 698-705. Portuguese. DOI: (https:// doi.org/10.1590/S0102-09352009000300025).

21. Carrijo AS, Fascina VB, Souza KMR de, Ribeiro SS, Allaman IB, Garcia AML, Higa JA. Níveis de farelo da raiz integral de mandioca em dietas para fêmeas de frangos caipiras. Revista Brasileira de Saúde e Produção Animal, Bahia, 2010; 11 (1). Portuguese. DOI: (https://dx.doi.org/10.4321/ S0004-05922011000300038).

22. COBB. Manual de manejo de frangos de corte Cobb. 2009. 65. Disponível em: (https://www.cobbvantress.com/assets/Cobb-Files/df5655a7e9/Broiler-Guide-2019-POR-WEB.pdf).

23. Campello CC, dos Santos M do SV, Leite AG dos A, Rolim BN, Cardoso WM, Souza FM. Características de carcaça de frangos tipo caipira alimentados com dietas contendo farinha de raízes de mandioca. Ciênc. anim. Bras, 2009; 10(4):1021-8. Disponível em: (https://www.revistas.ufg.br/vet/article/view/1230).

24. Holanda MAC de, Holanda MCR de, Vigoderes RB, Dutra Junior WM, Albino LFT. Desempenho de frangos caipiras alimentados com farelo integral de mandioca. Revista Brasileira de Saúde e Produção Animal, 2015; 16 (1): 106-117. Portuguese. DOI: (https://doi.org/10.1590/S1519-99402015000100012). 